\title{
Forecasting Load on PT PLN (Persero) Metro Substations (GI) Using Combined Methods for Electrical Needs in Metro City 2019 - 2029
}

\author{
Candra Saigustia ${ }^{1}$, Kiki Kananda ${ }^{2}$ \\ ${ }^{1}$ Program Studi Teknik Elektro Sekolah Tinggi Teknologi Nusantara Lampung \\ ${ }^{2}$ Program Studi Teknik Elektro, Institut Teknologi Sumatera \\ ${ }^{1}$ saigustia@gmail.com \\ ${ }^{2}$ khiekykananda@gmail. com
}

\begin{abstract}
Electricity consumption in Metro City has increased along with the increase in population, economic activity, technological progress and growth of households. Electrical energy is needed for the interests of industry, households and other activities as well as to support increasingly advanced technological developments The researcher used load forecasting with a combined method based on economic growth, population growth, and the growth of households in Metro City. The data used in this study are growth data that occurred from 2014 to 2018 . The results of this paper is forecasting the number of customers, load energy consumption (MWh), total energy requirements (MWh), connected power (kVA), and peak load (MW). Energy consumption growth every year has the same tendency as in previous years. In the household sector, energy consumption will grow higher each year than other sectors. In 2029, it estimated that the peak load that will occur at Metro substations, PT PLN (Persero) Rayon Metro City is 92.62 MW.
\end{abstract}

Keywords - Forecasting, Electrical Energy Needs, Combined Method, PT PLN, Metro City

\section{INTRODUCTION}

As the population increases and the economy grows, energy needs in the future, especially electricity, continue to increase. Electrical energy is needed for the interests of industry, households and other activities as well as to support increasingly advanced technological developments [1]. Therefore, with the rapid advancement of technology and the economic activities of the people, the demand for electricity in the future will continue to increase.

At present, the increasing demand for electricity is not offset by an increase in electricity supply. Community needs for electricity are increasing but the existing power capacity has not changed[3]. This causes rotating blackouts caused by a deficit in electricity, especially during peak loads, where the load of public electricity usage exceeds the available power. Therefore, the development of electricity supply needs to be done in the future such as the development of power plants, transmission and distribution systems and their control and protection systems[2]. Development of electric power generation, transmission and distribution requires high investment costs. If the development or increase the amount of power generation in not appropriate or too high will cause the waste of the investment cost and power[4]. On the other hand, if the power generation in the power plant is too small from the demand and electricity needs, it will cause a loss on the side of the consumer related to the continuity of disrupted power distribution.

To get the optimization of budgetary investment in the development centers of generation, transmission and distribution, the company needs to know the approximate number of load in the future [11]. With study on forecasting this load, a company budget can be prepared for the expansion of power line distribution and an increase in the number of power generation optimally along with the accuracy of the investment budget in accordance with the demand for the electricity needs of the community in the future[12]. The electricity demand increasing in the future must be met to support the progress of the economy and other activities. 
Forecasting the use of electricity in the future becomes very important information to make decisions or policies to expand and increase the number of distribution and the amount of power generation in a particular region[1]. For this reason, the construction of power plants, transmissions and distributions must be carried out precisely and efficiently as possible by forecasting electricity needs in the future before the electricity needs occur. Therefore, the development plan by means of predicting future energy requirements are needed.

In this study, researchers used secondary data from the Central Statistics Agency (BPS), PT PLN (Persero) Distribution Rayon Metro Lampung, the local government of Metro City, as well as other data relevant to the research of this thesis.

In this research aims to plan or forecast demand of electric energy in accordance with the demand and consumption of electrical energy in Metro City for a period of 10 years starting from 2019 until 2029.

\section{RESEARCH METHOD}

\section{A. Used Method}

The combined method is a method compiled by combining several models such as econometrics, trends, and analytics with a sectoral approach, namely an approach by grouping customers into 4 sectors (household, business, general, and industrial). This forecast is based on economic growth, population growth, and the growth of local households. The data used is growth over the previous five years.

The method used in this research is descriptive: to observe the development of the electric load on each type of burden on consumers in PT PLN Rayon Metro on projected power electrical loads are connected to forecast electrical energy demand, the number of customers connected power and the amount of load GI Metro at the PLN branch Metro City in the next ten years. To minimize the possibility of a deviation in the estimated load in the future, researchers used better and more accurate calculations for each load sector using the combined method [10].

\section{B. Data Collection}

In conducting data collection, the methods used are as follows:

\section{1) Study Literature}

The author collects the data in the form of literature sourced from theoretical books, manuals, magazines, reports, thesis papers, the internet and other data that support and are needed for the writing of final assignment reports on forecasting this burden, such as from the best agencies such as the Central Agency Statistics and PT PLN (Persero) branch Metro City.

\section{2) Observation}

At this stage, observations were conducted at PT PLN (Persero) Metro District to see the state of electricity usage in Metro City related to the amount of electricity used, number of customers, and Metro substation (GI) load data to determine the total load of transformers. The author takes the data from the two data sources are the Central Bureau of Statistics (BPS) and PT PLN Rayon Metro in support load forecasting calculations. To get data related to this thesis, the author made direct observations to PT PLN (Persero) Metro District, BPS Metro City, Central Lampung BPS and East Lampung BPS. Because the PLN Metro Area includes 3 administrative regions, namely: Metro City, East Lampung and Central Lampung, the data sources related to government or development data (GRDP growth) are taken from 3 different BPS and taken from the 3 regional governments. While the data limit used for this study is from 2014-2018 for data from BPS, and for data from PT PLN Metro Rayon taken from 2014-2018. The data taken are, GRDP growth, business GRDP growth, general GRDP growth, and industrial GDP growth, number of customers in each sector, and the amount of electricity sold in each sector. Of all the data taken will be processed to get the basic assumptions that will be used for forecasting calculations.

\section{Data processions}

This study uses secondary data of Metro City PLN in the form of peak load data (VA) Metro Substation (GI) and BPS Metro City, 
Central Lampung BPS and East Lampung BPS as the basis for calculations.

Then the researcher collects the data to be analysed according to the combined method as a load forecasting method in the literature. Then the data will be used as material for the analysis of load growth in the distribution transformer, analysis of distribution of load transformers, and analysis of the development time of the substation at PLN Rayon Metro City.

In this part of all the data obtained is processed to obtain the values, among others: the assumption of GDP growth (obtained from the average GRDP growth in 20142018), energy elasticity, customer factors, and the growth in the number of PLN Rayon Metro customers in the past 5 years (20132017), the unit of household electrical energy consumption and the growth in the amount of electrical energy consumption of PLN customers Rayon Metro 5 years back (2014-2018).

\section{Data Analyses}

After processing the data, calculations and analyses are carried out using a combined method, namely a method compiled by combining several calculation methods such as econometrics, trends, and analytical with a sectoral approach, namely an approach by grouping customers into 4 sectors (household, business, general, and industrial), then it can be known to customers in which sector has the greatest growth in energy consumption in the next ten years, customers in which sector has decreased continuously in the next ten years and the growth of total electrical energy burden of PT PLN (Persero) Rayon City Metro at ten years forward.

\section{RESULTS AND DISCUSSIONS}

\section{A. Existing Condition of PT PLN (Persero) Rayon Metro City}

1) Service Area

PT PLN (Persero) Rayon Metro is the smallest business unit of PT PLN (Persero) Distribution Lampung in carrying out the task of distributing electrical energy in Metro
City. PT PLN (Persero) Rayon Metro has six feeders to supply electricity in Metro City, namely Gurame, Sepat, Betok, Nila, Patin, Bawal. These two feeders come from Metro City Substation (GI).

Table 1. Customer Service Area Of Pt Pln (Persero) Rayon Metro City [9]

\begin{tabular}{|l|l|l|}
\hline No & Service Area & Feeder \\
\hline 1 & Kota Metro & $\begin{array}{l}\text { Sepat } \\
\text { Gurame }\end{array}$ \\
\hline 2 & Batanghari & Betok \\
\hline 3 & Sekampung & Nila \\
\hline 4 & Metro Kibang & Patin \\
\hline 5 & Trimurjo & Bawal \\
\hline
\end{tabular}

2) Population Conditions

Within 5 years (2013 - 2017), population density tended to increase along with the increase in population. On the other hand, the population distribution in each sub-district has not been evenly distributed. Based on data from the Metro City Central Statistics Agency (BPS), the average growth of the population of Metro City during 2013 - 2017 was $1.75 \%$. As for the number of households, the average growth is $2.31 \%$. With the highest growth in Metro Utara sub-district and the lowest in Metro Timur sub-district, each of $2 \%$ and $1.61 \%$.

Based on the PLN Branch Metro City service area as shown in table 4-1 above, the population and households served by PT PLN (Persero) Metro City will differ from the population of Metro City. With reference to BPS data, population growth and the number of household occupants during 2014 - 2018 for PT PLN (Persero) Metro City Rayon are presented in the table below:

Table 2. Population Per Year Metro City [7]

\begin{tabular}{|c|c|c|c|c|c|}
\hline \multirow{2}{*}{} & \multicolumn{5}{|c|}{ Total Population (person) } \\
\cline { 2 - 6 } & 2013 & 2014 & 2015 & 2016 & 2017 \\
\hline Metro & 140.3 & 142.9 & 145.4 & 147.0 & 149.3 \\
\hline
\end{tabular}

Table 3. Total Population Growth Per Year Metro City Per District [7]

\begin{tabular}{|c|l|c|}
\hline No & \multicolumn{1}{|c|}{ District } & Total Population \\
\hline 1 & Metro Selatan & 14434 \\
\hline 2 & Metro Barat & 25940 \\
\hline 3 & Metro Timur & 36021 \\
\hline
\end{tabular}




\begin{tabular}{|l|l|l|}
\hline 4 & Metro Pusat & 47358 \\
\hline 5 & Metro Utara & 25608 \\
\hline
\end{tabular}

Table 4. Population Of Metro City In 2018 Per District [7]

\begin{tabular}{|c|l|c|c|c|c|c|}
\hline \multirow{2}{*}{ No } & \multirow{2}{*}{ District } & \multicolumn{5}{|c|}{ Annual Population Growth (\%) } \\
\cline { 3 - 7 } & & $\mathbf{2 0 1 3}$ & $\mathbf{2 0 1 4}$ & $\mathbf{2 0 1 5}$ & $\mathbf{2 0 1 6}$ & $\mathbf{2 0 1 7}$ \\
\hline 1 & Timur & 1,9 & 2,2 & 1,7 & 2,4 & 1,8 \\
\hline 2 & Barat & 1,4 & 1,8 & 1,9 & 1.55 & 1,9 \\
\hline 3 & Selatan & 1,8 & 1,9 & 2,13 & 1,13 & 1,45 \\
\hline 4 & Pusat & 1,9 & 2,5 & 1,7 & 1,44 & 1,21 \\
\hline 5 & Utara & 1,72 & 2,09 & 1,42 & 1,72 & 1,13 \\
\hline
\end{tabular}

\section{3) Electrical Conditions}

The load of a city generally varies. Electric power users in Metro City can be classified as domestic / business, public, and industrial users. Based on the tariff group, the detailed classification of electricity users is as follows:

- Small and household users (tariff group R1, R2, R3)

- Business users (tariff groups B1, B2, B3).

- General users: government buildings / offices, public street lighting and social lighting. (tariff group S1, S2, P1, P2, P3)

- Industrial and hotel users (class I1, I2, I3, I4).

Table 5. Electrical Conditions Pt Pln (Persero) Metro City [9]

\begin{tabular}{|c|l|c|c|c|c|c|}
\hline $\begin{array}{l}\mathrm{N} \\
\mathrm{o}\end{array}$ & Sector & 2014 & 2015 & 2016 & 2017 & 2018 \\
\hline 1 & Energy & 442.84 & 471.67 & 480.3 & 450.6 & 465.83 \\
& Sold & & & 1 & & \\
& (MWh) & 314.7 & 339.2 & & 302.7 & 319.43 \\
& a. & 40.4 & 42,33 & 344.3 & 51,8 & 54.97 \\
& Household & 38,34 & 39,34 & 44,1 & 44,4 & 47.46 \\
& s & 49,4 & 50,8 & 40,71 & 51,7 & 43.97 \\
& b. Business & & & 51,2 & & \\
& c. Public & & & & & \\
& d. Industry & & & & & \\
\hline 2 & Power & 67,341 & 70,65 & 80,261 & 88,16 & 95,74 \\
& Connected & & 7 & & 4 & 8 \\
& (kVA) & 48,77 & & 58,795 & & \\
& a. & 8 & 51,21 & 8,977 & 64,82 & 71,021 \\
& Household & 7,921 & 4 & 7,238 & 1 & 9,389 \\
& s & 5,884 & 8,124 & 5,251 & 9,167 & 8,926 \\
& b. Business & 4,758 & 6,365 & & 8,090 & 6,412 \\
& c. Public & & 4,954 & & 6,086 & \\
& d. Industry & & & & & \\
\hline 3 & Customers & & & & & \\
& (person) & 81,44 & 81,44 & 81,447 & 81,44 & 87,898 \\
& a. & 7 & 7 & 62,542 & 7 & 82,511 \\
& Household & 5,456 & 59,77 & 2,345 & 76,75 & 2,746 \\
& s & 1,997 & 5 & 2,004 & 4 & 2,295 \\
& b. Business & 1,657 & 2,211 & 19 & 2,540 & 23 \\
& c. Public & 17 & 1,997 & & 2132 & \\
& d. Industry & & 18 & & 21 & \\
\hline 4 & Losses & 8.52 & 9.52 & 7.52 & 6.52 & 5.36 \\
5 & Energy & 480.57 & 516.6 & 516.4 & 479.9 & 490.8 \\
& Needs & & & & & \\
6 & (MWh) & 63.2 & 65.2 & 62.4 & 66.72 & 68.31 \\
& Peak Load & & & & & \\
(MW) & & & & & \\
\hline & & & & & & \\
\hline
\end{tabular}

Source: Data \& Statistics PT PLN (Persero) Rayon Metro 2014 2018

4) Economic conditions

The improving economic condition of Metro City can be indicated by positive economic growth, in 2013 the economy of Metro City was measured from GRDP growing by $4.75 \%$ and in 2018 it increased $5.35 \%$. In line with the improving economic development of Metro City, the economic performance of Metro City in 2013 increased by $5.50 \%$. For Metro Timur District, the increase was $3.86 \%$

Based on data from Metro City's Gross Regional Domestic Product (GRDP) in 20142018, GDP growth for each city in Metro in 2014 - 2018 can be labelled as follows:

Table 6. Total Growth Of Sectoral Grdp Per Year Metro City 2014 - 2018 [6]

\begin{tabular}{|l|l|l|l|l|l|l|}
\hline \multirow{2}{*}{ No } & \multirow{2}{*}{ District } & \multicolumn{5}{|c|}{ Growth Per year (\%) } \\
\cline { 3 - 7 } & & $\mathbf{2 0 1 4}$ & $\mathbf{2 0 1 5}$ & $\mathbf{2 0 1 6}$ & $\mathbf{2 0 1 7}$ & $\mathbf{2 0 1 8}$ \\
\hline 1 & Business & 3,25 & 4,49 & 5,47 & 7,45 & - \\
\hline 2 & Industry & 4,04 & 4,93 & 4,70 & 4,49 & - \\
\hline 3 & Public & 4,13 & 6,09 & 5,22 & 4,97 & - \\
\hline 4 & $\begin{array}{l}\text { GRDP } \\
\text { Total }\end{array}$ & 5,32 & 5.89 & 6.40 & 5,97 & - \\
\hline
\end{tabular}

\section{B. Assumptions Calculation Used}

After obtaining assumptions from data processing and analysis of secondary data obtained from PT PLN (Persero) Rayon Metro City and Metro City Central Bureau of Statistics (BPS), assumption calculations are used to predict the electrical energy requirements for Metro for the next 10 years then it can summarize in an overview of the assumptions about the preparation of forecasting electrical energy requirements as follows:

Table 7. Assumptions Calculation Forecasting Load [9]

\begin{tabular}{|l|l|c|}
\hline No. & & \\
\hline 1 & PUBLIC & \\
& 1. Population growth (\%) & 1,68 \\
& 2. GDP growth (\%) & 5,89 \\
\hline 2 & HOUSEHOLD SECTOR & \\
& 1. Number of people / households & 3.83 \\
& 2. Energy Elasticity & 2,3 \\
& 3. Target of electrification ratio 2030 & 100 \\
& 4. Average connected power / new & 1.077 \\
& customer (VA) & \\
\hline 3 & BUSINESS SECTOR & 2.14 \\
& 1. Customer Elasticity & 3.27 \\
& 2. Energy Elasticity & 5.16 \\
& 3. Business sector GRDP growth (\%) & \\
\hline
\end{tabular}




\begin{tabular}{|l|l|c|}
\hline & 4. Average connected power / new & 6303 \\
customer (VA) & \\
\hline 4 & PUBLIC SECTOR & \\
& 1. Customer Elasticity & 1.92 \\
& 2. Energy Elasticity & 3.11 \\
& 3. Business sector GRDP growth (\%) & 4.63 \\
& 4. Average connected power / new & 5846 \\
\hline 5 & customer (VA) & \\
& INDUSTRY SECTOR & 2.12 \\
& 1. Customer Elasticity & 1.82 \\
& 2. Energy Elasticity & 5.44 \\
& 3. Business sector GRDP growth (\%) & \\
& 4. Average connected power / new & 172000 \\
\hline
\end{tabular}

Source: Data \& Statistics PT PLN (Persero) Metro City 2014 2018

\section{Forecasting Results of Electric Energy Needs}

So after the calculation is based on data calculated assumptions previously with the Microsoft Excel program, the results of the forecast for electrical energy for the city of Metro 2019-2029 are obtained. The results of the forecasts made can be seen in the table below:

Table 8. Forecasting Load Results Of Pt Pln (Persero) Metro City 2014-2024

\begin{tabular}{|c|c|c|c|c|}
\hline $\mathrm{N}$ & Sector & 2018 & 2025 & 2029 \\
\hline 1 & $\begin{array}{l}\text { Total Growth of } \\
\text { Households (\%) }\end{array}$ & $\begin{array}{l}40.321 \\
7,56 \\
\end{array}$ & $\begin{array}{l}44.559 \\
10,51 \\
\end{array}$ & $\begin{array}{c}46.843 \\
5,12 \\
\end{array}$ \\
\hline 2 & $\begin{array}{l}\text { Energy } \\
\text { Consumptions } \\
\text { (MWh) } \\
\text { a. Households } \\
\text { b. Business } \\
\text { c. Public } \\
\text { d. Industry }\end{array}$ & $\begin{array}{c}511.985,178 \\
\\
359.583,016 \\
54.970,928 \\
47.460,753 \\
49.970,481\end{array}$ & $\begin{array}{c}773.918,600 \\
\\
621.503,469 \\
54.976,493 \\
47.465,270 \\
49.973,368\end{array}$ & $\begin{array}{l}964.894,3 \\
71 \\
\\
812.470,5 \\
94 \\
54.980,20 \\
4 \\
47.468,28 \\
1 \\
49.975,29 \\
2\end{array}$ \\
\hline 3 & $\begin{array}{l}\text { Power Connected } \\
\text { (kVA) } \\
\text { a. Households } \\
\text { b. Business } \\
\text { c. Public } \\
\text { d. Industry }\end{array}$ & $\begin{array}{c}103.303 .047 \\
\\
77.222 .039 \\
9.789 .432 \\
9.879 .348 \\
6,412,144\end{array}$ & $\begin{array}{c}120.865 .269 \\
\\
90.657 .295 \\
12.244 .259 \\
11.551 .304 \\
6,412,411\end{array}$ & $\begin{array}{c}133.894 .1 \\
91 \\
\\
100.635 .9 \\
57 \\
14.066 .68 \\
2 \\
12.778 .96 \\
4 \\
6,412,588\end{array}$ \\
\hline 4 & $\begin{array}{l}\text { Customers } \\
\text { a. Households } \\
\text { b. Business } \\
\text { c. Public } \\
\text { d. Industry }\end{array}$ & $\begin{array}{c}89.725 \\
84.551 \\
2.810 \\
2.341 \\
23\end{array}$ & $\begin{array}{c}103.076 \\
97.222 \\
3.199 \\
2.632 \\
23\end{array}$ & $\begin{array}{c}113.062 \\
106.705 \\
3.488 \\
2.846 \\
23\end{array}$ \\
\hline 3 & $\begin{array}{l}\text { Energy Needed } \\
\text { (MWh) } \\
\text { Peak Load (MW) }\end{array}$ & $\begin{array}{c}525.095 .663 \\
69,7\end{array}$ & $\begin{array}{c}828.092,902 \\
73.95\end{array}$ & $\begin{array}{c}1.032 .436 \\
, 977 \\
92.62\end{array}$ \\
\hline
\end{tabular}

\section{Discussion of Forecast Results}

The results of the estimated calculations able to discuss / analysed as follows:

1) Total Energy Consumption
From the results of the forecast, the total energy consumption for Metro City could be illustrated as follows:

ETt

$$
\begin{aligned}
& =\mathrm{ERt}+\mathrm{EBt}+\mathrm{EUt}+\mathrm{EIt} \\
& =\mathrm{ER} 2014+\mathrm{EB} 2014+\mathrm{EU} 2014+\mathrm{EI} 2014 \\
& =336.149 .814+54.970 .928+47.460 .753+49.970 .481 \\
& =488.551 .976 \mathrm{kWh}
\end{aligned}
$$$$
\mathrm{ET}_{2014}=\mathrm{ER} 2014+\mathrm{EB} 2014+\mathrm{EU} 2014+\mathrm{EI} 2014
$$

With:

ETt: Total electricity consumption in year $t$.

ERt: Household sector energy consumption in yeart

EBt: Business sector energy consumption in year $\mathrm{t}$.

EUt: Public sector energy consumption in year $\mathrm{t}$.

EIt: Energy consumption of the industrial sector in year $\mathrm{t}$

Total energy consumption at PT PLN (Persero) Rayon Metro City in 2014 amounted to 550.2 MWh with the highest electricity consumption in the household sector, amounting to $397.8 \mathrm{MWh}$

\section{2) Total Energy Need}

The electrical energy needs have to be produced /provided are the amount of total energy consumption and energy losses. Energy losses in Metro City in 2019 - 2029 estimated to be $7.48 \%$ annually:

Then the total energy requirements able to predicted as follows:

$$
\begin{aligned}
\mathrm{PTt} & =\mathrm{ETt}+\mathrm{Set} \\
\mathrm{PT} 2014 & =\mathrm{ET} 2014+\mathrm{SE} 2014 \\
& =488.551 .976+(7,48 \% \times 488.551 .976) \\
& =488.551 .976+36.543 .687 \mathrm{kWh} \\
& =525.095 .663 \mathrm{kWh}
\end{aligned}
$$

With:

PTt: The total electric energy needs in year $t$ ETt: Total electricity consumption in year $t$

SEt: Energy losses in year $\mathrm{t}$

The total energy needs of Metro City show a pattern of development that is almost the same as the pattern of growth in energy consumption. In 2018 the largest energy needs were $81.6 \mathrm{MW}$.

\section{3) Peak Loads (MW)}

The peak load forecast based on total energy production and load factors: 


$$
\begin{aligned}
\mathrm{BPt} & =\mathrm{PTt} /(\mathrm{FBt} * \mathrm{JOt}) \\
\mathrm{BP} 2014 & =\mathrm{PT} 2014 /(\mathrm{FB} 2014 * \mathrm{JO} 2014) \\
& =525.095 .663 /(0.86 \times 8.760) \\
& =525.095 .663 / 7533 \\
& =69.7 \mathrm{MW}
\end{aligned}
$$

With:

BPt : Peak load in year to $t$ (MW)

PTt: Total energy requirements in year $t$

FBt : Load factor in year $t$.

Jot : Operating hours for a certain period (8,760 hours / year)

From the results of the peak load forecast for Metro City Rayon Substation it can be seen that the realization of the highest peak load in 2018 was 68.31 MW. In accordance with the development of energy consumption and energy losses, it is estimated that in 2029 the peak load will reach 92.62 MW.

\section{E. CONCLUSIONS}

Electric energy consumption in Metro City increases frequently with increasing population, increasing economy, and growing households. Growth in energy consumption each year has the same trend as in previous years. In the general sector, energy consumption will grow higher each year compared to other sectors. In 2018 the energy needs of PT PLN (Persero) Rayon Metro City amounted to 490.8 MWh. Whereas in 2029 it must provide energy of 1,002.6 MWH. In accordance with the development of energy consumption and energy losses, it is estimated that in 2029 the peak load that occurs at PT PLN (Persero) Rayon Metro City is 92.62 MW.

\section{REFERENCE}

[1] K.L. Ho, Y.Y. Hsu, C.C. Yang, Short Term Load Forecasting Using A Multilayer Neural Network With An Adaptive Learning Algorithm, IEEE, 1992.

[2] Francisco J. Nogales, Javier Contreras, Antonio J. C, Rosario E, "Forecasting Next-
Day Electricity Price by Time Series Models". IEEE Transsactions On Power System, Vol.17, No. 2, May 2002.

[3] Fitrianto, Kurniawan. 2006. Prakiraan Kebutuhan Energi Listrik Tahun 2006-2015 Pada PT. PLN (Persero) Unit Pelayanan Jaringan (UPJ) di Wilayah Kota Semarang. Makalah Seminar Tugas Akhir. Semarang:Teknik Elektro Fakultas Teknik UNDIP.

[4] L. Tobing, Bonggas, 2010. Peralatan Tegangan Tinggi. Jakarta: PT. Gramedia Pustaka.

[5] Annonymus, Penyusunan Prakiraan Kebutuhan Listrik. Dinas Penelitian Kebutuhan Listrik, PLN Pusat, Jakarta, 1992.

[6] Herman Darnel Ibrahim, Rencana Usaha Pengusahaan Tenaga Listrik (RUPTL) 2006- 2015, Direktorat Transmisi dan Distribusi PT. PLN (Persero), Jakarta, 2006. [3] Francisco J. Nogales, Javier Contreras, Antonio J. C, Rosario E, “ Forecasting Next-Day Electricity Price by Time Series Models". IEEE Transsactions On Power System, Vol.17, No. 2, May 2002.

[7] Annonymus, Metro Dalam Angka Tahun 2014, 2015, 2016, 2017, 2018, Metro, 2018.

[8] Annonymus, Kabupaten Lampung Timur Dalam Angka Tahun 2009, 2010, 2011, 2012, 2013, Metro, 2013.

[9] Annonymus, Data dan Statistik Tahun 2014, 2015, 2016, 2017, 2018, PT. PLN (persero) Rayon Kota Metro, Metro, 2018.

[10] Supranto, J, Metode Ramalan Kuantitatif Untuk Perencanaan, Gramedia, Jakarta, 1998.

[11] Moch. Muchlis, Proyeksi Kebutuhan Listrik PLN Tahun 2003-2020, Dinas Perencanaan Sistem PT. PLN (Persero), Jakarta, 2004.

[12] Oetomo TW. Pelatihan Perencanaan Energi, Pusat Informasi Energi, Departemen Energi dan Sumber Daya Mineral dan Energi Analysis and Policy Office (EAPO), Jakarta, 2004.

[13] Sulasno, Ir., Teknik dan Sistem Distribusi Tenaga Listrik, Badan Penerbit UNDIP, Semarang, 2004. 